\title{
Ethnographic artifacts and value transformations
}

\author{
Rosita Henry, James Cook University \\ Ton OTTO, James Cook University \\ Michael WoOD, James Cook University
}

Transactions of ethnographic artifacts between Indigenous producers, European collectors, museums, and the state create and transform multiple notions of value. In this paper we discuss how an artifact's value is generated and transformed through various transactions linked to the documentation and property claims made by scientific collectors, such as Eric Mjöberg, Herman Klaatsch, and Ursula McConnel. Such artifacts have now entered a new dynamic given Aboriginal claims for repatriation and other forms of reappropriation. We argue that the entanglement of artifacts in the property claims of the collectors, the producers (or their descendants), the granting bodies, and the public institutions, exposes artifacts to complex processes of value accretion and transformation.

Keywords: anthropology of value, Aboriginal Australian artifacts, North Queensland, collectors, museums, Eric Mjöberg, Ursula McConnel

We can say, as did the New Guinea man Yali when he found his community's sacred objects in an Australian Museum, "Our myths are there. . . ."

James Weiner, The lost drum

On October 31, 1905, the Brisbane Courier reported that during a sitting of the Queensland Parliament, when the matter of the reappointment of Dr. Roth to the position of Chief Protector of the Aborigines was raised, a debate ensued in regard to artifacts that he had collected in Queensland and sold to the Australian Museum in Sydney. The newspaper made the point that if Dr. Roth was collecting "ethnological specimens," "curios," and "articles" while employed by the Queensland Government,

then it is only natural that some explanation should be made as to why a proportion of the curios should have found their way to a Southern

(c) This work is licensed under the Creative Commons

(C) Rosita Henry, Ton Otto, and Michael Wood.

Attribution-NonCommercial-NoDerivs 3.0 Unported. ISSN 2049-1115 (Online) 
Museum to the number of 2000, whilst the Queensland Museum has to be satisfied with some 300 . No information has been made available as to the comparative value of the articles sent respectively to Sydney and to our local Museum; but the contention has been that Dr. Roth has made a specially valuable collection which has certainly not been deposited in the Queensland Museum. (Brisbane Courier, October 31, 1905)

Of interest to the Brisbane Courier was the problem of the financial, comparative, and special value of what we now call artifacts. The value of Roth's collection was partly financial but also involved other values, such as Queensland state honor. While the Members of Parliament and the Brisbane Courier seemed able to freely articulate their concerns about the value of the artifacts, Roth himself was silent for a time, apparently unable or unwilling to take a stance on the value transactions into which he had entered:

With regard to the alleged sale of curios and ethnological specimens . . . Dr. Roth did not at that time offer nor has he since offered any explanation. . . . It would be a great pity if the usefulness of the Chief Protector of the Aborigines were to be jeopardised for want of a reasonable explanation of transactions that obviously need to be put clearly before the public. (Brisbane Courier, October 31, 1905)

This account of Roth's dealings with the Australian Museum indicates that transactions in artifacts always raise questions regarding the value of the items transacted. Moreover, it highlights that issues of standing, accountability to various publics, identity, and property claims are intrinsic to questions of value.

In this article we discuss how value is generated and transformed through various inscriptions of meanings, transactions, and property claims concerning museum artifacts. ' We focus on artifacts collected in north Queensland by scientific collectors, such as Walter Roth (McDougall and Davidson 2008), Hermann Klaatsch (Erckenbrecht 2010), Eric Mjöberg, and Ursula McConnel and then consider how Aboriginal people reappropriate such objects today (Erckenbrecht et. al. 2010). We argue that their entanglement in the property claims of the collectors, the producers (or their descendants), the granting bodies, and public institutions, exposes artifacts to complex processes of value accretion and transformation. We are interested in the different forms of value that are attributed and denied to artifacts in the transactions between these different interested parties. For example, we examine how artifacts accrue prestige value (via the identity, name, and reputation of the producers, collectors, and institutional recipients), monetary value (as in the Roth example), and barter value as "duplicates" in museum transactions (Knapman 2009; White 2007). We are less interested in the kinds of value creation undertaken by museums and other institutions in terms of display and exhibition than on the collected object and its transformation into a specific kind of entity (a museum artifact) saturated with social relations that prevent it from becoming the exclusive property of public institutions. Our account of artifact transactions emphasizes the tensions, linkages, and blurred boundaries between conceptions of artifacts as public goods, as subject to other ownership claims, and

1. We emphasize museums here, as that is where most of the objects we consider in this paper are now found. 
as containing gift-like qualities. Artifacts, and the social interactions that establish their properties, escape easy categorization in terms of the well-established dichotomies between gifts and commodities, individual and public ownership (Gregory 1982; Thomas 1991).

\section{Artifact as object and documentation}

We define an artifact as a complex phenomenon, consisting of a collected material thing, its specific documentation, and the stories and theories that give it a history. It is the compositeness of artifacts that poses a particular analytical challenge as well as the key to understanding their trajectories of valuation and devaluation. Building on others before us, such as Webb Keane (2005), Robert Foster (2012), and Joshua Bell and Haidy Geismar (2009), and deploying insights from Tim Ingold (2012: 434), we treat the artifact's value and materiality as historical process. As Ingold (2012: 435) notes, "in the phenomenal world, every material is a becoming." Collected materials become artifacts and gather values through the very process of their collection, documentation, movement, and flow through various hands. Yet, not all hands have equal power and, thus, the values gathered into artifacts do not necessarily have equivalent sociopolitical weight. The practices involved in the creation, movement, and flow of artifacts accrete value for some at the same time as value is eroded for others (Were 2012).

Ingold $(2011,2012)$ analyzes such flows by deploying a clear-cut distinction between objects and things, inspired by Heidegger's understanding of an object as standing over and against the perceiver, whereas a thing is seen as a process of becoming through action, movement, and transformations of properties. Ingold tends to value becoming over objectification, but in our reading of this conceptual opposition artifacts are both becoming and objectified at the same time. That is, they are part of a process of objectification through the activities of producers, collectors, buyers, researchers, and publics, but they are also things that are embedded in relational networks of transformation. We find the conceptual distinction useful to consider the different processes of valuation artifacts become part of during their "social life" and to emphasize an inherent tension between the two opposite tendencies they are subjected to. To start with, any form of inscription, categorization, and explanation of a collected thing makes it into an object that represents a certain value for the collector or objectifier. This value can, for example, be that the artifact represents a specific cultural specimen or typology, or illustrates a pet theory. The assigned value of the collected object enters further transformation and objectification when the collector exercises his or her ownership and agency concerning the object in relation to other possible claimants, whether individual or collective actors, such as the original producers, the funding agencies, and public institutions for cultural heritage such as museums. In the ongoing negotiations between these agents, artifacts may be subjected to contrasting objectifications (such as those of commoditization versus gift relations). The point here is that each reobjectification implies a revaluation of the artifact, for example when descendants of the original producers wish to reappropriate artifacts that

2. For further discussion of the concept of the "document" in reference to artifacts see Bernd Frohmann (2009) and Michael Buckland (1997). 
might provide a potential physical linkage to their ancestors. ${ }^{3}$ Thus artifacts are born in "processes of flow and transformation" and then have lives that oscillate between "continual modulation" (Ingold 2012) and objectification. It is in the very tension or contradiction between flow and fixity, thing and object, that value is created. ${ }^{4}$

In the following, we trace the activities of different collectors and the value transformations of their artifacts. We begin with Eric Mjöberg as an example of early collectors in the region, such as Klaatsch and Roth, who had strong personal involvement in their collections but simultaneously commodified them. Then, by way of contrast we consider Ursula McConnel, who was explicitly prohibited from commodifying her collection but partially privatized it, as exemplified in her ability from the 1930 s to the 1950 s to shift large parts of her collection from Sydney University to the Queensland Museum and then to the South Australian Museum (Edwards 1968). ${ }^{5}$ Both cases highlight the collector's ability to variously exert control over the disposition of their collections in ways that are independent of their initial funders and other institutions with interests in the collections. Finally, we consider contemporary transformations and objectifications of artifacts by descendants of the original producers, who reassess the artifacts as things but also confront and appropriate earlier objectifications by the collectors.

\section{Eric Mjöberg and his beeswax figure}

Mjöberg was a trained Swedish zoologist (entomologist) who undertook two expeditions to Australia to collect zoological and botanical specimens. While employed by the Swedish Museum of Natural History, Mjöberg acquired various grants that allowed him to lead a group of four scholars, including himself, to the Kimberley in Western Australia in 1910-11. A grant from an exclusive Traveller's Club in Stockholm provided to him the means for a second Australia trip, this time traveling alone to the Cairns region and Cape York in 1912-13 (Ferrier 2006). During both expeditions Mjöberg also made ethnographic collections and observ-ations and eventually published two books on his adventures and discoveries (Mjöberg 1915, 1918). It is his second trip to the Cairns region and

3. Our theoretical perspective is in line with Lambek's (part two of this special issue) argument that action is the source of all value but we reserve a clear role for the materiality of artifacts. Human acts of objectification create certain valuations of an artifact, but its materiality as a thing carries these different valuations across contexts defined by potentially conflicting projects of different actors.

4. We follow collections of artifacts across different contexts of manufacture, collection, exchange, and reappropriation in a way suggested by George Marcus's concept of multisited ethnography (1995), but complement this approach with a strong temporal dimension through historical research. Anna Tsing (part one of this special issue) also follows the value transformations of objects across space and time but with a much shorter time horizon, determined by the lifespan of the mushrooms she studies. Artifacts often exceed the lifetimes of the original producers and collectors as we show in the cases we describe.

5. Other artifacts collected by McConnel ended up in the National Museum of Australiafor some details on parts of this process see David Kaus (2008) and Nan Goodsell and Leonie Oakes (1988). 
Cape York Peninsula that interests us here. He did not write much about his practices of collection, but from dispersed statements in his publications and from analyzing his notebook (Åsa Ferrier, personal communication) it is clear that he used a range of means to obtain the objects or "etnografika" he desired: from buying, via bartering, to simply taking. At the time of his travel, many rainforest Aboriginal people had already been settled in mission stations like Yarrabah, close to Cairns. Mjöberg writes that these Aboriginal people were encouraged by the mission to "mass produce" weapons and other utensils for sale in order to create income for the station (Mjöberg 1918: 240, 242). As some of the objects in Mjöberg's collection derive from Yarrabah (Ferrier 2006: 8, and collection 1920.14 at the Ethnographic Museum Stockholm) it is likely that he acquired them for money. Thus, some of the objects he collected were already commodity-like at the time of their production. But Mjöberg actually despised the missions and especially the missionaries, who in his view caused serious damage to the Aboriginal people through their processes of "civilization." Although he presumed Aboriginal people to be at a lower stage of human cultural evolution, he considered that they exemplified a fascinating, well-adapted, and valuable form of life that deserved to be preserved and protected.

The artifact we follow here resulted from events in Malanda (upper North Johnstone River). Mjöberg tells us that he had felled a rainforest tree with a bee's nest in it and examined the nest for insects (Mjöberg 1918: 509-11). He gave the honey-filled combs to an old Aboriginal man who had been watching him and who, according to Mjöberg's Indigenous assistant, had never before seen a white man (1923: 88). Several days later Mjöberg met the same man in his shelter modeling a male figure out of the wax from the comb. To Mjöberg's great interest the old man finished his figure by attaching a large penis to it "to mark the masculine character of the figure” (Mjöberg 1918: 510, our translation). This apparently created extra value for Mjöberg because he could connect this figure with a theory and narrative about phallic cults among Australian Aborigines. He writes that the little sculpture was of great importance, because it was the first find of its kind and could throw light on latent phallic concepts among the Aborigines (Mjöberg 1918: 510). He mentions that he had found phallic forms carved in stone during his first trip to the Kimberley region, in north Western Australia. He saw the phallic cult as a complex of basically latent concepts and emotions among Aboriginal people and speculated that it may have come to Australia through migration from certain tribes in India, among whom this cult was prominent in the past. The topic was of sufficient interest to him to later publish a short article in an anthropological journal, in which he refers to other reports from Western Australia, South Australia, Victoria, and New South Wales (Mjöberg 1923). In this article he also mentions that he had heard from a reliable person that phallus forms were made from beeswax in the savannah area of the Cape York Peninsula, but that he had not been able to find them. Through these publications Mjöberg created an artifact in the sense described above, comprising the thing sculpted by a local person, his original documentation in his notebook, and a theory discussed in an academic article and popular book on the north Queensland expedition.

On his return to Sweden Mjöberg offered part of his collection of rainforest artifacts to the National Museum of Ethnography in Stockholm. It is a small collection of about 110 objects that attempts to provide a comprehensive overview 
of the livelihood and culture of the Aboriginal people of the far-north Queensland rainforest. It is likely that he negotiated a price for the collection, but the museum has kept no record of this acquisition, which it secured around 1913 but only registered in 1920. Mjöberg kept a considerable part of his collection and sold items to private collectors when he needed money. He also gave some artifacts as gifts to friends and colleagues (Ferrier 2006: 10). The beeswax figure was eventually transacted for honor. Together with eleven artifacts from Borneo (from a later collection) Mjöberg offered the wax figure to the Danish National Museum in Copenhagen in 1927. In the accompanying letter of March 14, 1927 ${ }^{6}$ addressed to his "close friend" the director of the museum, he refers to his two publications in which the phallic figure is described. "I take the liberty to send you 12 etnografica. Number one is the original [underlined in the letter] of the phallic figure reproduced in my book. . . . You can find a full description of the object in the book (page 510). It is also reproduced and described in my little report 'Vom Phalluskult in Nordaustralien’ Arkiv f. Anthropologie. N.F. Bd. XIX, Heft 2/3. P. 86-88." Soon thereafter, the director received a letter from the Ministry of Foreign Affairs saying that the Danish king had knighted Eric Mjöberg (Ridder af Dannebrog). Thus Mjöberg finally parted with his valuable artifact not, as far as his correspondence indicates, for money but for royal acknowledgement and distinction. This account underlines the collector's personal involvement in these kinds of objects, which were often treated as personal property even though the expedition was paid for by public funds. Mjöberg created the artifact through his expedition, through his dealings with the old Aboriginal man, his notes, and his story making. It thus carried part of his person and would in this sense make a perfect gift. But the object was also part of other identities: the original maker and the culture he represented; the public funding agencies that facilitated the expedition; the academic community who could acknowledge the scientific value of the object through the theory it proved or illustrated; the general public who visited the museum. By transacting the artifact for royal honor, Mjöberg received something other than money in return for his personal involvement in the object. Placing the artifact in a public museum would acknowledge and support the complex multiple identities connected with it: those from the collector, original producer, funding agent, academic community, and general public. The figure is still displayed in the permanent exhibition of the Danish National Museum bearing witness to these multiple identities as well as the reputation of its collector.

\section{Ursula McConnel: Artifact value as transactable property}

Australian born, Ursula McConnel (1888-1957) was trained as an anthropologist at University College London and then supervised by Radcliffe-Brown at the University of Sydney. She did fieldwork in far-north Queensland, which included the collection of ethnographic artifacts. On Cape York McConnel reciprocated the Wik Mungkan with presents of tobacco and fishing line, while in the Cairns region she paid the Kunggandyi and Yidinji with money provided by the Australian National Research Council (O’Gorman Perusco 2008: 433; O’Gorman 1989: 26). One of the primary objectives of her 1930 field trip was to collect artifacts

6. Archived in the museum as J1660 C2937-47. 
(O'Gorman Perusco 2008: 433). Most of the one hundred items she collected on this trip came from Yarrabah Mission, or its immediate surrounds, such as Fitzroy Island. The artifacts were made mainly by Kunggandyi and Yidinji people. Since very few of these artifacts display any signs of use, they probably mainly represent the output of specially commissioned work (O’Gorman 1989: 81).

The Australian National Research Council (ANRC) functioned from 1919 to 1955 and, in the 1920s and 1930s, used funds provided by the Rockefeller Foundation to document Aboriginal culture (Mulvaney 1993; Peterson, Allen, and Hamby 2008: 11). The ANRC funded McConnel's work along with that of Lloyd Warner, C. W. Hart, Lauriston Sharp, Donald Thomson, and others (Hamby 2008: 359; Bonshek 2004). All were asked to make collections as part of their research and these collections were understood to be mainly the property of the ANRC. Such artifacts were not to be sold in any market even if they were understood to be the property of the collector. In contrast to the collections of Roth, Klaatsch, and Mjoberg, artifact collections by researchers were to be fully decommodified:

Any complete field research will normally include the collection of objects of ethnographical interest. Any object so collected shall be the property of the ANRC. The fieldworker will be expected to label and index the collection. In general, permission will be granted to the field worker to keep for himself, or to present to ethnological museums, a limited number of duplicate specimens. He shall not however, dispose of specimens by sale. If the recipient of a grant wishes to make a collection for some museum, he must obtain permission beforehand from the Committee on Anthropological Research. (Goodsell and Oakes 1988: 10)

In effect, researchers could keep objects or donate objects from their collection as long as the Department had an "example" (Hamby 2008: 359). As Louise Hamby (2008: 359) notes, "a murky area of ownership of objects and their 'duplicates' was to emerge from this accepted arrangement." Duplicates enable transactions to take place. The existence of the duplicate is determined by distinctions such as place of collection and producer that are made by the collector as they document the collection. Also relevant is an assessment by the collector (and by the curator) of the producer's creativity and skill/craftsmanship and the overall scarcity of the product. Being defined as duplicate enhanced the capacity of that artifact to enter into long distance flows of exchange. ANRC Board minutes from 1930 note, "permission was granted for the presentation of duplicate specimens from the collections made by our field workers, to the Bishop Museum, Honolulu and to the Fitzwilliam Museum Cambridge" (Elkin cited in Goodsell and Oakes 1988: 6). It seems that for a time the ANRC exercised a right to alienate elements of the collections they funded but this right was dependent on the existence of duplicates. Exactly the same qualified right was extended to the grant recipients. With the approval of the Committee on Anthropological Research, a body that advised the ANRC on the grants, any recipient could engage in other collecting activities. But all recipients were explicitly prohibited from selling such collections; they could only "present" their duplicate collections to museums or keep them as private possessions. This enforced decommodifation of artifacts made the collectors more like donors and gift givers than market participants with private property to sell. 
Initially the Sydney University's Department of Anthropology was eager to retain the collections of their researchers and it was "expected that the collections would remain in the department" (Hamby 2008: 370). By 1929 it became apparent that the department had a storage problem. Thus, Radcliffe-Brown argued the Anthropology collection should be given to the proposed National Museum of Ethnography in Canberra (Goodsell and Oakes 1988: 10). McConnel's artifacts remained at Sydney University until 1935. According to O'Gorman Perusco (2008: 437) it was not until late 1934, after her last fieldwork trip, that McConnel attempted to move the collections from Sydney closer to her home in the Brisbane region. Permission to move the artifacts to the Queensland Museum was influenced by the insistence of A. P. Elkin (then head of Anthropology) and Sydney University that they belonged to the ANRC, and "could only be let out on loan to museums” (Elkin cited in O'Gorman1989: 3). Elkin's view was that the collection was on "temporary loan," and would have to be returned within a reasonable amount of time (O’Gorman Perusco 2008: 437).

Yet, despite these views, Elkin himself did not always observe the ANRC protocols. In one of his more emotional interventions into talks about transactions involving McConnel's artifacts in 1937 he wrote to her about artifacts loaned to the Commonwealth Government's Paris Exhibition Committee:

\begin{abstract}
The ANRC has also loaned the Committee a few specimens of material culture, each duly ticketed with name of article and collector; some of your collection amongst them. I did not let any of your shields go as there was no time to ask you, and in any case I should miss them, even for a few months. ... (Elkin to McConnel 9 February 1937, Sydney University Archives 41633 [2])
\end{abstract}

Despite Elkin exercising control over some of the artifacts McConnel had collected-and effectively privatizing the shields-during her life McConnel asserted and enacted a number of quite effective property claims over her other artifacts. For example, in 1951 she expressed the view that the ANRC's interest in the artifacts was not confined to courteous recognition of "prior assistance," but did extend to legal ownership. However, she thought this claim was unenforceable given the researcher's "effort," "ability," and "training" or what we might now call intellectual property. In 1951 she argued:

I think legally the ANRC has the right to . . . own . . . the material collected by fieldworkers, but I do not think they would press this claim. Account must be taken of the field worker's personal effort and ability and training for which the Grant was given. (McConnel cited in O’Gorman Perusco 2008: 439)

She was right insofar as the ANRC, on Elkin's advice, allowed her to shift the artifacts to the Queensland Museum in 1935, where they "still in their packing cases remained virtually untouched" until the director wrote to Elkin highlighting their poor condition (O'Gorman Perusco 2008: 438). It appears that McConnel never inspected the collection until Elkin asked her to check it. Subsequently, Elkin, representing Sydney University and the ANRC, agreed to McConnel's 
request that the artifacts be removed from the Queensland Museum to the South Australian Museum in Adelaide.?

In negotiations with the South Australian Museum McConnel represented the artifacts as hers-a point she thought would be corroborated by the Queensland Museum:

In a letter to Cleland [at the South Australian Museum] she states "the Queensland Museum Director regards the specimens as mine and would deliver them to me on request. My only reason for not accepting, is, that I have no where safe to put them and do not wish to be discourteous to ANRC in recognition of those members of it who have been so helpful to me in the past." (McConnel to Cleland August 23, 1947 in O'Gorman Perusco 2008: 439)

She also argued that some of the artifacts were in fact her own and that she was free to "offer" them to other institutions such as the South Australian Museum "in return for their assistance" (O'Gorman Perusco 2008: 439). She argued that as "I myself received gifts and paid for some things I could consider I had some claim [on them]" (O'Gorman Perusco 2008: 439).

By 1949 McConnel's artifacts had been moved from the Queensland Museum to the South Australian Museum. The museum director outlined much of the material transferred as a loan of limited duration:

Miss McConnel has donated to the Museum a selection of specimens which are her own property. The whole collection is remaining at the Museum at least for a year. . . . It is hoped that some arrangement may be made whereby at least a good part of her collection will remain permanently in this Museum. (Hale to The Chairman of the Museum Board 10 February 1949. Board Papers AA191 South Australian Museum [SAM] Archives)

When McConnel's collection arrived at the South Australian Museum, officially on "loan" from Sydney University and the ANRC, she carefully catalogued the collection herself making sure that her name and relevant references to her publications were recorded as part of the documentation (O'Gorman Perusco 2008: 440). Such curatorial practice fosters strong identification between a collector and an artifact and grants the artifact a biographical history merged with that of the collector. The collector Hermann Klaatsch actually wrote his name in pencil on the artifacts that he collected and his inscriptions are carefully preserved by the curators in the Cologne museum today (Erkenbrecht 2011: 26-7, 35).

Direct inscription of data on to the artifact fuses it with its documentation. This fusion extends to other forms of documentation in particular publication of articles, photographs, and drawings about the artifacts. For McConnel, publication

7. But even McConnel's concerns about her ownership of the collection could not prevent some of her artifacts-now based in Adelaide-simply becoming lost over time (O'Gorman 1989: 32-36). Most of her notebooks also seem to have been lost, apart from some that have recently emerged into the public domain (Sutton 2010, 2006). 
created authenticity effects that legitimated curatorial intervention and "retouching" of objects. ${ }^{8}$ In a 1949 letter to Tindale she argued:

I think that the shields etc could be retouched if Elkin is agreeable and Miss Walsh is prepared to do it. The clays are there and as the shields have been published there is no question of doubt as to authenticity. Art in Australia with the article in "Inspiration and Design in Aboriginal Art" is in the library. I gave Mr Hale [the Director of SAM] a copy for the Museum. (Anthropology and Archaeology [AA] 298 AA Correspondence December 1948-49. Box 3. SAM Archives)

The possibility of display is in McConnel's account also enhanced by publication. McConnel, in the same 1949 letter as cited above, noted:

it might be as well to wait the completion of the record for publications before exhibiting. The shields etc from Yarrabah and the bull-roarers etc have been published and could be shown anytime.

A specific understanding of publication emerges here. It authorizes and authenticates the display of the artifact. The artifacts themselves are appropriate bibliographic sites for reference to such publications and other forms of documentation (labels, inscriptions of collectors' names and numbers). Publication, in creating for the artifact an authenticating effect, can also seemingly take the place of the original. McConnel's account implies publication is like the original while the artifact itself becomes more duplicate-like and hence can be physically transformed (retouched) and subject to curatorial interventions without fear it will be considered inauthentic by such activities. The tenor of these ideas and practices is to make artifact and documentation transactionally bound together, even mutual-ly transformable. McConnel's "publication" has the effect of enlivening the object into a potential flow of value-enhancing intervention (repainting).

Once she had finished cataloguing her collection at the South Australian Museum, McConnel proceeded to further assert her control of the artifacts. She made plans for the further redistribution of parts of her collection (sets) to interested institutions. The possibility of these additional transactions and claims rested partly on the existence of "spares" and "duplicates":

Of the duplicates or spares I made up a set (chiefly spears, dilly bags and necklets, armlets etc) for the Sydney University. . . . I also chose duplicates of spears and necklets etc and some other objects for South Australian Museum. These are all labeled for SA Museum. All other spares I would like kept till my return-as I may be glad of some myself or other Museums may like them. In a case I put aside dillybags and necklets etc (all spares) which I particularly want to use myself for publication and do not want disturbed. . . (McConnel to Tindale 9 February 1949 AA 298 AA Correspondence December 1948-49. Box 3 SAM Archives)

8. Publication provides proof of provenance for both Museum artifacts and those in the commodified artifact market. Publication also provides a useful aura of gravitas to any artifact. 


\section{Indigenous value of artifacts}

Along with maintaining her control of her collections McConnel was also interested in Indigenous modes of value creation in reference to artifacts. Her 1935 article on the artifacts she collected in Cairns can be understood as offering a contrast to the earlier collectors such as Roth, Klaatsch, and Mjöberg for whom an artifact tended to be part of a process where the individual, original producer was not acknowledged. McConnel was interested in naming and photographing producers such that if for earlier collectors one dominant social form of an artifact was as a private extension of the collector, in her Cairns-based work an artifact was an extension of the collector as well as the original producer.

McConnel's 1935 article was also an attempt to describe what, following Fred Myers (2005: 97) we might call a "revelatory regime of eliciting value" that derives from the ontology of the Dreaming. She and her Yarrabah interlocutors draw together stories of ancestral creativity, the naming of places and natural entities, and the designs painted on the artifacts she collected. The key term in her analysis is buleru (now often represented as buluru), which can be glossed as ancestral creator figure or Dreaming. It has been translated into a wide range of meanings such as "the Story-time, any people, places or things from that time; sacred places and things" (Dixon 1991: 149) and "father's father, country, mythical ancestor" (Sharp 1938-9: 271).

McConnel outlined several stories of totemic ancestors (buleru) that mention names of both places and natural species. She indicated links between these kinds of buleru and the designs found on bark shields, cross boomerangs, and other objects:

The ceremonial paddles were made by Kurabana men. Of the five designs two are buleru on Mira Warikal [King Beach] i.e. the crocodile and the lawyer cane (kwi.gi.), whilst another, the saw shark, Dya:gara, a son of Ngunya. A fourth is ka:ndor, the leaves of which plant were used as a cure for stinging nettle. The fifth is Kudyu-kudyu, the rainbowserpent, who is the very incarnation of the stormy season and appropriately therefore one of the greatest of the Kurabana buleru. (McConnel 1935: 53)

McConnel also provided some evidence of people being named after buleruassociated species. She noted that Dick and Alex of Mira Baki, who used the Kudyu-kudyu design on the paddle, were "called respectively Yimbung'gai after 'the thunder' and Dyinadi.gar after the freshwater eel and oyster ('because he cut his foot on one' was the rationalised explanation), all of which 'belonged' to Kudyu-Kudyu, the rainbow serpent buleru” (McConnel 1935: 54). ${ }^{9}$ In addition to

9. Later, in 1966, Alice Moyle $(1968,1972)$ recorded songs at Yarrabah that refer to totems that McConnel had recorded in stories, and in the designs on the artifacts she had collected. Moreover, some of Moyle's recordings were also enacted in dance:

Among the songs (dira) on this disk are some which are performed during dances or dance acts (warma) for the entertainment of visitors to Yarrabah. The danced or mimed series usually included Windmill (actually cross-boomerang), Seagull, Crocodile and Rainbow Snake (Kudyu-Kudyu). A notable feature of the Rainbow Snake act is a large 
these kinds of identification between design, dreaming, and person, by including the names and photographs of some of the producers of the artifacts she collected, McConnel forged further links between the artifacts, the producers, and their descendants.

However, McConnel had no "direct evidence" that the designs on the objects were

deliberately derived from buleru. The Kunggandyi who made them are not themselves conscious of any such connection. Yet it was they who told me these "stories" and gave me the names of the designs which so aptly coincide with the buleru. (McConnel 1935: 55)

She notes that her Yarrabah interlocators were no longer fully engaged in their culture. Her documentation here is something less a set of confirmed propositions or determinate meanings and more a set of displacing uncertainties.

We think this is how many attempts to establish the cultural value of artifacts as objects proceed. McConnel provides evidence of a local theory of value creation (via buleru), and an outline of some the processes that undermined the possibility of this mode of value production from ensuring its own reproduction. She offers an historical analysis of the decline of the revelatory mode of value production she describes.

Nevertheless, elements of this kind of value production continue to be both reproduced and transformed in the contemporary context. This occurs via new kinds of transactions in iconic artifacts of the north Queensland rainforest region (bicornual baskets, large painted shields, long heavy hardwood swords, and ornately painted cross-boomerangs) (Kahn 2000). During the 1980s, Aboriginal people in the region began to actively re-engage with things made by their ancestors and held captive in museums since the early part of the twentieth century. These artifacts are implicated in new forms of value transformation that partly embed them in an intensified Indigenous moral economy of kinship and the inalienable. ${ }^{10}$

Things, once removed to museums along various routes including transactions with collectors (such as Klaatsch, Mjöberg, Roth, and later, McConnel), are today defined as "our culture" and "rendered transactable" as "cultural heritage" (Strathern 2004: 94). These artifacts have sometimes been the subject of collective property claims and of attempts to reassert and reinvigorate values that were historically curtailed through the objectification practices of collectors and museums. But what is more important for some Aboriginal people is the practical value of the artifacts, that is, their value as a means of learning the almost lost art of their production and their importance for cultural renaissance.

Also involved are assertions of inalienable kinship ties between artifacts, their original producers, and the current generation. Some artifacts are said to be imbued not just with the generalized ancestral spirit (buluru), as described by McConnel, but with the actual blood, sweat, and spirit of genealogically traceable ancestors. These ancestors (old people) are believed to be able to authorize the

cane basket which represents the open mouth of the snake. (Moyle 1968: 3)

10. This is analogous to the conversions between gift and commodity highlighted in Tsing's paper in part one of this special issue. 
reproduction of these objects-and particularly the totemic designs said to be painted on them-by individual contemporary artists they recognize as kin. It is not a matter of collectively asserted communal rights but of debts and responsibilities entailed in specific kinds of intergenerational relationships that involve transactions in bodily substances. The old people may no longer be alive, but they once held these objects in their hands or close against the sweat of their bodies and some objects, such as the shields, are believed to have been painted with ochre mixed with the blood of the painter. In 2011, an Aboriginal man from Yarrabah at the Cairns Indigenous Arts Fair said he was investigating having DNA tests done on the painted shields in museums, to find evidence of connections between the original shield-painters and their descendants today. He noted that while documentation in relation to shields held in museums sometimes provides the name of the place it was collected, or perhaps even a tribal name, this level of identification was insufficient. What Aboriginal people seek, he said, is not a broad, generic place or tribal name but the identification of a shield in terms of the actual individual who painted it and the specific local place in which he did so. Thus, what is of value to him and perhaps other Aboriginal people immersed in the contemporary politics of heritage and native title, is evidence of shared substance and the ability of a shield to act as a tangible link with the "old people." Of value is the potential of a shield's painted totemic design to substantiate connections to the ancestors and, through them, to the land itself.

\section{Conclusion}

We have tracked the creation of artifacts and transformations of their value across a number of interactional contexts. Our histories of artifacts, exceeding the lifetimes of the original producers and collectors, linked accounts of contextually specific value transformations to more persisting conceptual and political tensions that informed the specific objectification of those artifacts (Munn 1986). We described tensions among forms of privatization enacted by the collectors and simultaneous attempts to create forms of public ownership through documentation, publication of reports, registration, and through the claims of public institutions involved in the artifacts. Attempts to shift artifacts into various kinds of public domain did not just enhance a notion of the artifact as stabilized into public property but also amplified the artifact as an individual entity containing and maintaining social and proprietary relationships. Artifacts were often positioned within the porous boundaries and conversion processes evident between the private and public. While our historical cases reveal that the commodity/gift opposition was at times relevant as in Mjöberg's case, notions of privatization, as evident in McConnel's property-like claims over her artifacts, were often in tension with the formation of permanent public goods that could be transacted only by museums and other state authorized institutions. The various values of artifacts considered here cannot be fully captured in terms of the analytical distinction between gifts and commodities even though they were often given and traded, and nor can they be easily captured by reference to the private/public distinction since, as we have seen, artifacts were often both public property and privately transactable at the same time.

We suggest that these dualisms are part of a more fundamental process of objectification and flow that engenders artifacts as composite phenomena with the 
potential of simultaneous diverging valuations by different actors. Here we are inspired by the recent theorizing in material culture studies and ecological anthropology (Ingold 2012), where artifacts can be understood as both "becoming things" and "objects." In our analysis it is the tension between these two aspects of an artifact that gives rise to continuous revaluation. While every semantic categorization of the artifact is in fact a process of objectification-making a thing into an object-the thing itself persists as a potential for transformation and revaluation. This capacity to enter human action and movement is what defines a thing, according to Ingold. But an artifact, while being a flow of materialities, also often carries its objectifications across different situations. This happened for example, when Mjöberg highlighted the value of his personal gift to the National Museum in Copenhagen by referring to his publications in which he connected one of the objects to theoretical speculation about phallic cults. And McConnel's work to catalogue all the artifacts transferred from the Queensland museum not only made her collection more useful to the interested public, including other scholars, but also increased her agency and control over the objects. Cataloguing enabled her to identify "duplicates" and "spares" that she could keep in her private possession or distribute to other museums. Finally, contemporary claims and reappropriations by Australian Aboriginal groups focus on the material thing that was made by their ancestors and still may have traces of their bodily involvement. Simultaneously, these claims were guided by older objectifications, indicating places and names, and even cultural interpretations as in McConnel's case with the patterns on the shields. But, they are also informed by contemporary relations and new objectifications, such as the possibility of DNA testing. Thus, artifacts go through various fluctuations in value over time and may be loaded with several objectifications simultaneously. But such objectifications are not politically neutral and, therefore, artifacts are never merely amalgams of equivalent values. In the final analysis, it is the artifact's treatment as a thing in often conflicting real life interactions that determines and actualizes its values at any one moment.

\section{Acknowledgments}

The research for this article was funded by an Australian Research Council (ARC) Discovery grant for the project "Objects of possession: Artifact transactions in the Wet Tropics of North Queensland, 1870-2013” (DP110102291). We have benefitted immensely from discussions with the other investigators involved in this research project, including Shelley Greer, Russell McGregor, Maureen Fuary, Corinna Erckenbrecht, Trish Barnard, and Bård Aaberge. We are also grateful to the conveners of the conference at which this paper was first presented. We especially thank the discussant for our paper, Robert Foster, and the other participants at the conference for their insightful comments and feedback. We thank staff of the many museums where we have conducted research. Crucial for this article were Lea Gardam of the South Australian Museum; Julia Mant and Nyree Morrison of Sydney University Archives; Bente Wolff of the Danish National Museum; Hakan Wahlquist and Anita Utter of the Museum of Ethnography in Stockholm; Elin Bornemann of the Pitt Rivers Museum; Jo 
Dudding of the Museum of Archeology and Anthropology, Cambridge University; Lissant Bolton, Jill Hassell, and James Hamill of the British Museum.

\section{References}

Bell, Joshua, and Haidy Geismar. 2009. "Materialising Oceania: New ethnographies of things in Melanesia and Polynesia." The Australian Journal of Anthropology 20 (1): 3-27.

Bonshek, Elizabeth. 2004. "Ownership and a peripatetic collection from Tikopia, Solomon Islands.” Records of the Australian Museum, Supplement 29: 37-45.

Buckland, Michael K. 1997. "What is a 'Document'?" Journal of the American Society for Information Science 48 (9): 804-9.

Dixon, Robert. M. W. 1991. Words of our country: Stories, place names and vocabulary in Yidiny, the Aboriginal language of the Cairns-Yarrabah region. St Lucia: University of Queensland Press.

Edwards, Robert. 1968. "The South Australian Ethnographic Collection." Mankind 16: 673-75.

Erckenbrecht, Corinna. 2010. Auf der Suche nach den Ursprüngen: Die Australienreise des Anthropologen und Sammlers Hermann Klaatsch 19041907. Ethnologica N.F. 27. Köln: Wienand Verlag.

Erckenbrecht, Corinna, Maureen Fuary, Shelley Greer, Rosita Henry, Russell McGregor, and Michael Wood. 2010. "Artefacts, collectors and the definition of a 'region' in the tropics of North Queensland." The Australian Journal of Anthropology 21: 350-66.

Ferrier, Åsa. 2006. "Dr Eric Mjöberg 1913 scientific exploration of North Queensland's rainforest region." Memoirs of the Queensland Museum Cultural Heritage Series 4 (1): 1-27.

Frohmann, Bernd. 2009. "Revisiting "What is a document?" Journal of Documentation 65 (2): 291-303.

Foster, Robert. 2012. "Notes for a networked biography: The P.G.T. Blackwood Collection of Oceanic things.” Museum Anthropology 35 (2): 149-69.

Goodsell, Nan, and Leonie Oakes. 1988. The University of Sydney Anthropology Collection. Unpublished Manuscripts. The Australian Museum.

Gregory, Chris A. 1982. Gifts and commodities. London: Academic Press.

Hamby, Louise. 2008. "The reluctant collector: Lloyd Warner.” In The makers and making of indigenous Australian museum collections, edited by Nicholas Peterson, Lindy Allen, and Louise Hamby, 354-86. Carlton: Melbourne University Press.

Ingold, Tim. 2011. Being alive: Essays on movement, knowledge and description. London: Routledge. 
- 2012. "Toward an ecology of materials." Annual Review of Anthropology 41: 427-42.

Kahn, Kate. 2000. "Adornments and design in north Queensland: A view from the nineteenth century.” In The Oxford companion to Aboriginal art and culture, edited by Sylvia Kleinert and Margo Neale, 180-84. South Melbourne: Oxford University Press.

Kaus, David. 2008. "Professionals and amateurs: Different histories of collecting in the national ethnographic collection." In The makers and making of Indigenous Australian museum collections, edited by Nicholas Peterson, Lindy Allen, and Louise Hamby, 280-86. Carlton: Melbourne University Press.

Keane, Webb. 2005. "Signs are not the garb of meaning: On social analysis of material things.” In Materiality, edited by Danny Miller, 182-205. Durham, NC: Duke University Press.

Knapman, Gareth. 2009. "Exchanges and the historical construction of the collection.” In Inspiring action: Museums and social change, edited by Graeme Farnell, 56-73. London: Museums Etc.

Marcus, George E. 1995. "Ethnography in/of the world system: The emergence of multi-sited ethnography.” Annual Review of Anthropology 24: 95-117.

McConnel, Ursula H. 1935. "Inspiration and design in Aboriginal art." Art in Australia 59: 49-68.

McDougall, Russell, and Iain Davidson, eds. 2008. The Roth family, anthropology, and colonial administration. Walnut Creek, CA: Left Coast Press Inc.

Mjöberg, Eric. 1915. Bland vilda Djur och Folk i Australien. Stockholm: Alerts Bonniers Förlag.

——. 1918. Bland Stenåldersmänniskor i Queenslands Vildmarker. Stockholm: Alberts Bonniers Förlag.

—— 1923. Vom Phalluskult in Nordaustralien. Archiv für Anthropology 19 (4): 86-88.

——. 1925. Beiträge zur Kenntnis der Eingeborenen von Nord-Queensland. Archiv für Anthropology 20 (2-4): 108-35.

Moyle, Alice. 1968. "Aboriginal music on Cape York." Journal of the Musicological Society of Australia 3: 3-20.

—. 1972. "Introductory notes to songs from Yarrabah.” In Songs from Yarrabah. Canberra: Australian Institute of Aboriginal Studies.

Mulvaney, Derek John. 1993. "Australian anthropology since Darwin: Models, foundations and funding." Scientia Canadensis: Canadian Journal of the History of Science, Technology and Medicine, 17 (1-2): 153-83.

Munn, Nancy. 1986. The fame of the Gawa: A symbolic study of value transformation in a Massin (Papua New Guinea) society. Durham, NC: Duke University Press. 
Myers, Fred. 2005. "Some properties of art and culture: Ontologies of the image and economies of exchange." In Materiality, edited by Danny Miller, 88-117. Durham, NC: Duke University Press.

O'Gorman, Anne. 1989. "Ursula McConnel: The archaeology of an anthropologist." BA honours thesis, Australian National University, Department of Anthropology and Prehistory.

O’Gorman Perusco, Anne. 2008. "Only stick and bark: Ursula McConnel-her collecting and collection.” In The makers and making of Indigenous Australian Museum Collections, edited by Nicholas Peterson, Lindy Allen, and Louise Hamby, 419-45. Carlton: Melbourne University Press.

Peterson, Nicholas, Lindy Allen, and Louise Hamby. 2008. "Introduction.” In The makers and making of Indigenous Australian museum collections, edited by Nicholas Peterson, Lindy Allen, and Louise Hamby, 1-26. Carlton: Melbourne University Press.

Sharp, Lauriston. 1938-9. "Tribes and totemism in north-east Australia. Oceania 9: 254-75, 439-61.

Strathern, Marilyn. 2004. "Transactions: An analytical foray." In Transactions and creations: Property debates and the stimulus of Melanesia, edited by Eric Hirsch and Marilyn Strathern, 85-109. New York: Berghahn Books.

Sutton, Peter. 2006. "Unexpected treasure: Surprise discovery of early anthropological papers by Ursula McConnel in Adelaide.” Anthropology Today 22: 21.

—_. 2010. "Ursula McConnel's tin trunk: A remarkable recovery." Transactions of the Royal Society of South Australia 134 (1): 101-14.

Thomas, Nicholas. 1991. Entangled objects: Exchange, material culture, and colonialism in the Pacific. Cambridge, MA: Harvard University Press.

Weiner, James. 1995. The lost drum: The myth of sexuality in Papua New Guinea and beyond. Madison: University of Wisconsin Press.

Were, Graeme. 2012. "Extreme collecting: An introduction” In Extreme collecting: Challenging practices for 21st century museums, edited by Graeme Were and J. C. H. King, 1-15. Oxford: Berghahn.

\section{Artefacts ethnographiques et transformation de valeur}

Résumé : Les transactions d'artefacts ethnographiques entre les producteurs indigènes, les collectionneurs européens, les musées et l'Etat contribuent à créer et à transformer les multiples notions de la valeur. Dans cet article, nous examinons comment la valeur d'un artefact est générée et transformée par différentes transactions liées aux revendications de droit à la propriété et à la documentation de collectionneurs scientifiques tels que Eric Mjöberg, Herman Klaatsch, et Ursula McConnel. Ces artefacts sont maintenant entrés dans une nouvelle dynamique 
insuflée par les revendications autochtones de rapatriement et d'autres formes de réappropriation. Nous soutenons que l'enchevêtrement des artefacts dans les revendications de propriété de la part des collectionneurs, des producteurs (ou leurs descendants), des organismes subventionnaires et des établissements publics, expose les artefacts à des processus complexes d'accrétion et de transformation de valeur.

Rosita HENRY is currently serving as head of the Department of Anthropology, Archaeology, and Sociology, at James Cook University. Her research concerns relationships between people, places, and the nation-state in Australia and the Pacific as expressed through heritage and the politics of cultural festivals and other public performances. She is author of the book Performing place, practicing memory: Indigenous Australians, hippies and the state (Berghahn Books, 2012) and of several papers on performative politics, including "Performing tradition: The poetic politics of indigenous cultural festivals" in The arts and the state edited by Judith Kapferer (Berghahn Books, 2008) and is coeditor with Barbara Glowczewski of the book The challenge of Indigenous peoples: Spectacle or politics? (Bardwell Press, 2011).

\title{
Department of Anthropology \\ James Cook University \\ Townsville, QLD 4811 \\ Australia \\ Rosita.Henry@jcu.edu.au
}

Ton OTto is Professor and Research Leader at James Cook University, Australia, and professor of Anthropology and Ethnography at Aarhus University, Denmark. Currently, he is directing the Ethnographic Collections at Moesgaard Museum, Aarhus. He is the editor (with Nils Bubandt) of Experiments in holism: Theory and practice in contemporary anthropology (Wiley-Blackwell, 2010) and (with Wendy Gunn and Rachel Smith) of Design anthropology: Theory and practice (Berg 2013). He also codirected the films Ngat is dead: Studying mortuary traditions (DER, 2009, with Christian Suhr and Steffen Dalsgaard) and Unity through culture (DER, 2012, with Christian Suhr).

\author{
Anthropology, Cairns Institute \\ James Cook University \\ Cairns QLD 4870 \\ Australia \\ ton.otto@jcu.edu.au
}

Michael WOOD is a Senior Lecturer in Anthropology in the School of Arts and Social Sciences, James Cook University. He has research interests in PNG concerning resource politics, land tenure, HIV/AIDS, and other aspects of social change. He has also worked in the Northern Territory and in North Queensland, 
mainly on issues related to the recognition of Indigenous land rights. He is the author of numerous articles on the Kamula, Western Province, PNG. He has explored some of these issues recently in "Mesede and the limits of reciprocity in field work at Kamusi, Western Province, Papua New Guinea.” The Asia-Pacific Journal of Anthropology 2 (2013): 126-35.

\author{
Department of Anthropology \\ James Cook University \\ Cairns QLD 4870 \\ Australia \\ michael.wood@jcu.edu.au
}

